Letter to the Editor

\title{
Octreotide and hepatocellular carcinoma
}

\author{
F Farinati*,', A Sergio', A Baldan', P Zucchetta ${ }^{2}$ and VD Corleto ${ }^{3}$ \\ 'Department of Surgical and Gastroenterological Sciences, Venetian Institute of Oncology (IOV), Padua University, Padua, Italy; ${ }^{2}$ Department of Diagnostic \\ Medical Sciences, Padua University, Padua, Italy; ${ }^{3}$ Department of Digestive and Liver Diseases, II School of Medicine, University 'La Sapienza', Rome, Italy
}

British Journal of Cancer (2007) 96, 1778- 1779. doi: I0.1038/sj.bjc.6603799 www.bjcancer.com

Published online 15 May 2007

(c) 2007 Cancer Research UK

Sir,

The treatment of advanced hepatocellular carcinoma (HCC) in patients no longer eligible for surgical, percutaneous or transarterial therapies is dismal. Chemotherapy, anti-estrogens or antiandrogens, retinol derivatives or stem cell factors have been tested with poor results, and we eagerly wait for the results of 'biologic' treatments, such as sorafenib.

Since the first enthusiastic report on Octreotide (Kouroumalis et al, 1998), in which HCC patients were characterized by somatostatin receptor expression and survival was significantly longer in the octreotide-treated arm, several papers have been published that almost constantly failed in confirming these preliminary data (Yuen et al, 2002; Slijkhuis et al, 2005).

The recent papers by Cebon in the British Journal of Cancer (Cebon et al, 2006) and by Becker in Hepatology (Becker et al, 2007) are a kind of obituary to the use of the drug in HCC and will probably lead to a definite stop to any attempt to treat HCC with octreotide, which is also an expensive drug. Indeed, in the two studies not only had the drug no impact on survival, even the quality of life was absolutely unaffected by the treatment. In the former study, only about $50 \%$ of the patients had a positive Octreoscan, while in the latter, the receptor status was not assessed. One could therefore say that the chances for the drug to work in receptor-negative patients are quite small. In previous papers, the percentage of receptor-positive patients was not defined (Treiber et al, 2006) or showed wide variability (Reynaert et al, 2004), even in relation to the type of receptor tested (Blaker et al, 2004).

In Italy, the rules for prescription require a positive Octreoscan as mandatory and we therefore recruited 25 consecutive patients diagnosed in the last 6 months, who had advanced stage HCC, according to the American Association for the Study of Liver Disease (AASLD) (Bruix and Sherman, 2005) (Table 1) and performed the imaging technique. In contrast with that found by Cebon, only $2 / 25$ $(8 \%)$ patients tested positive. Both had multifocal disease, hepatatis $\mathrm{C}$ virus-related aetiology, one had a large size HCC (Figure 1) and very high $\alpha$-fetoprotein levels $\left(245.000 \mu \mathrm{g} \mathrm{dl}^{-1}\right)$. One of the two refused the treatment. The second soon became intolerant, developed diarrhoea and nausea, interrupted the treatment after 2 months and died of upper gastrointestinal bleeding at 4 months.

As in our experience, the somatostatin receptor (SSTR) expression in HCC is independent of tumour stage, differentiation,

*Correspondence: Dr F Farinati; E-mail: fabio.farinati@unipd.it

Published online I5 May 2007
Table I Clinical features of the HCC patients recruited

\begin{tabular}{|c|c|c|}
\hline Variables & $N($ total 25$)$ & $\%$ \\
\hline \multicolumn{3}{|l|}{ Gender } \\
\hline Male & 20 & 80 \\
\hline Female & 5 & 20 \\
\hline \multicolumn{3}{|l|}{ Aetiology disease } \\
\hline $\mathrm{HBV}$ & 1 & 4 \\
\hline $\mathrm{HCV}$ & 16 & 65 \\
\hline Alcohol (+/- viruses) & 8 & 31 \\
\hline \multicolumn{3}{|l|}{ AFP } \\
\hline$<20 \mathrm{ng} \mathrm{dl}^{-1}$ & 8 & 31 \\
\hline $20-\left.200 \mu \mathrm{g}\right|^{-1}$ & 10 & 42 \\
\hline$>200 \mu \mathrm{g}^{-1}$ & 7 & 27 \\
\hline \multicolumn{3}{|l|}{ Lesion number } \\
\hline $1-3$ & 7 & 29 \\
\hline$>3$ & 18 & 71 \\
\hline \multicolumn{3}{|l|}{ Tumour size } \\
\hline$<5 \mathrm{~cm}$ & 19 & 74 \\
\hline$>5 \mathrm{~cm}$ & 6 & 26 \\
\hline \multicolumn{3}{|c|}{ Edmonson's grade of differentiation(in patients biopsied) } \\
\hline Well differentiated & 5 & 71 \\
\hline Moderately differentiated & 2 & 29 \\
\hline
\end{tabular}

Abbreviations: AFP, $\alpha$-fetoprotein; HBV, hepatitis B virus; $\mathrm{HCV}$, hepatitis $\mathrm{C}$ virus.

underlying liver disease and/or histological type (Blaker et al, 2004) and none of these parameters is therefore predictive of somatostatin analogue treatment response. As said, selection of HCC patients with more sensitive methods of SSTR expression (reverse transcription - polymerase chain reaction or immunohistochemistry, among which a high correlation is present), have not and will not change the picture. The clinical availability of new synthetic SSTRs pan-inhibitors such as SOM230 or BIM-23A779 (high affinity for SSTR1, SSTR2, SSTR3, SSTR5), could define whether the low or absent of in vivo effect on proliferation and apoptosis of the available analogues is related to the incapacity to stimulate a specific SSTR subtype or to a generally modest antiproliferative activity of these receptors (Reynaert et al, 2004). 


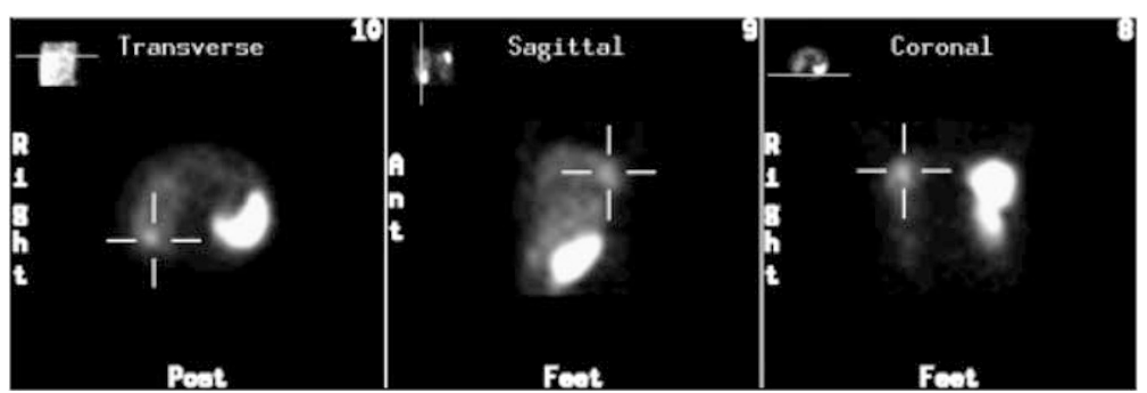

Figure I Octreotide Scintigraphy showing pathologic uptake in right liver lobe and normal uptake in spleen.

\section{ACKNOWLEDGEMENTS}

We thank Dr Domenico Rubello, Nuclear Medicine Service, Rovigo Hospital, for his valuable contribution to the study that was supported in part by Grants by the Veneto Region Institute of Oncology (IOV), in Padua, and by MURST.

\section{REFERENCES}

Becker G, Allgaier HP, Olschewski M, Olschewski M, Zahringer A, Blum HE, HECTOR Study Group et al (2007) Hector Study Group Long-acting octreotide versus placebo for treatment of advanced HCC: a randomized controlled double-blind study. Hepatology 45(1): 9-15

Blaker M, Schmitz M, Gocht A, Burghardt S, Schulz M, Broring DC, Pace A, Greten H, De Weerth A (2004) Differential expression of somatostatin receptor subtypes in hepatocellular carcinomas. J Hepatol 41(1): 112-118

Bruix J, Sherman M (2005) Management of hepatocellular carcinoma. Hepatology 42(5): $1208-1236$

Cebon J, Australasian Gastro-intestinal Trials group (AGITG) and Ag0001H Investigators (2006) Somatostatin receptor expression, tumour response, and quality of life in patients with advanced hepatocellular carcinoma treated with long-acting octreotide. Br J Cancer 95(7): 853-861

Kouroumalis E, Skordilis P, Thermos K, Vasilaki A, Moschandrea J, Manousos ON (1998) Treatment of hepatocellular carcinoma with octreotide: a randomised controlled study. Gut 42(3): $442-447$

Reynaert H, Rombouts K, Vandermonde A, Urbain D, Kumar U, BioulacSage P, Pinzani M, Rosenbaum J, Geerts A (2004) Expression of somatostatin receptors in normal and cirrhotic human liver and in hepatocellular carcinoma. Gut 53(8): 1180-1189

Slijkhuis WA, Stadheim L, Hassoun ZM, Nzeako UC, Kremers WK, Talwalkar JA, Gores GJ (2005) Octreotide therapy for advanced hepatocellular carcinoma. J Clin Gastroenterol 39(4): $333-338$

Treiber G, Wex T, Rocken C, Fostitsch P, Malfertheiner P (2006) Impact of biomarkers on disease survival and progression in patients treated with octreotide for advanced hepatocellular carcinoma. J Cancer Res Clin Oncol 132(11): 699-708

Yuen MF, Poon RT, Lai CL, Fan ST, Lo CM, Wong KW, Wong WM, Wong BC (2002) A randomized placebo-controlled study of long-acting octreotide for treatment of advanced hepatocellular carcinoma. Hepatology 36(3): $687-691$ 